\title{
Ocena rozwoju uszkodzenia zmęczeniowego warstwy aluminidkowej na stopie niklu z zastosowaniem technik nieniszczących
}

\author{
Assessment of development \\ of fatigue damagethe aluminide layer \\ on the nickel alloyusing non-destructive techniques
}

\section{Streszczenie}

W artykule przedstawiono wyniki badań w zakresie identyfikacji i lokalizacji pęknięcia warstwy aluminidkowej na stopie niklu, pod wpływem obciążeń zmęczeniowych, z zastosowaniem nieniszczących technik badawczych. Testom zmęczeniowym poddano próbki ze stopu niklu z warstwą aluminidową o grubości ok. 20 i $40 \mu \mathrm{m}$ uzyskaną w procesie chemicznego osadzania z fazy gazowej CVD (Chemical Vapor Deposition). Do identyfikacji uszkodzenia zdefiniowanego jako pęknięcie warstwy wykorzystano metodę prądów wirowych (ET) oraz optyczną metodę elektronicznej interferometrii plamkowej (ESPI). Ta ostatnia metoda pozwoliła na wykrycie pęknięć tworzących się w czasie cyklicznego obciążenia próbki, w oparciu o wskazanie lokalizacji deformacji. Umożliwiło to ocenę trwałości zmęczeniowej warstwy, której pękanie poprzedza uszkodzenie całej próbki.

Słowa kluczowe: nadstopy niklu, badania zmęczeniowe, wartswy aluminidkowe, prądy wirowe

\begin{abstract}
The paper presents results of fatigue test conducted on nickel based superalloy MAR 247 with aluminide layer of varying thickness. The trial for identification of damage localization with the use of Eddy Current (ET) and Electronic Speckle Pattern Interferometry optical method (ESPI) was made. It allowed for detection of cracks forming during cyclic loading of the sample. This enabled evaluation of fatigue life of the layer, as the formation of crack precede sample decohesion. Based on the fatigue tests created Wöhler curves were assigned for the samples with the aluminide layer of 20 and 40 microns thickness.
\end{abstract}

Keywords: super-nickel alloy, fatigue testing, alumina layer, eddy current.

\section{Wstęp}

Obróbka powierzchniowa żaroodpornych stopów niklu jest powszechnie stosowane w celu poprawy ich odporności cieplnej w warunkach pracy, np silników turbinowych, w których temperatura może osiągać do $1650^{\circ} \mathrm{C}$ (przy wylocie z komory spalania). Warstwa ochronna zwiększa odporność w warunkach korozji i erozji wysokotemperaturowej, co pozwala na zwiększenie temperatury pracy. Jednakże poprawa wytrzymałości cieplnej stopów przez pokrycie warstwą aluminidkową może spowodować spadek odporności na pełzanie i jak wytrzymałości na zmęczenie. Celem przeprowadzonych badań było określenie wpływu obecności i grubości warstwy dyfuzyjnej na właściwości mechaniczne stopu oraz na mechanizm powstawania uszkodzenia. Pewną trudność stanowi jednak identyfikacja momentu pęknięcia warstwy, które inicjuje pęknięcie osnowy i określa dynamikę jego propagacji. Ocena trwałości zmęczeniowej warstw dyfuzyjnych zwykle ogranicza się do obserwacji mikrostruktury próbek po kolejnych cyklach obciążenia. Metodologia ta jednak obarczona jest błędem bowiem każdorazowe usunięcie próbki z maszyny wytrzymałościowej powoduje zmianę warunków obciążenia, co znacząco zmniejsza wiarygodność wyników. Możliwość zastosowania nieniszczących technik wykrywania pęknięcia, bez konieczności usuwania próbki z maszyny aż do jego zniszczenia, stwarza stałe warunki obciążenia. W tym względzie pomocna okazała się standardowa metoda diagnostyczna oparta na indukcji prądów wirowych oraz ESPI, który pozwala na generować pole przemieszczenia na powierzchni próbki, w wybranych cyklach obciążenia.

\section{Materiał i metodyka}

Próbki poddane badaniam o geometrii pokazanej na rysunku 1 wykonano ze stopu niklu o oznaczeniu MAR 247 oraz następującym składzie chemicznym, w procentach wagowych: Cr-25\%, Mo-0.5\%, Co- $20 \%$, Al-0.9\%, Ti- $1.8 \%$, Nb$2 \%, \mathrm{Mn}-0.3$, Fe- $0.7 \%$, Si-0.5\%, C- $0.03 \%$, Ni-pozostałe. Proces nakładania warstwy aluminidkowej przeprowadzony był techniką CVD z zastosowaniem $\mathrm{AlCl}_{3} \mathrm{w}$ atmosferze wodoru, w temperaturze $1020{ }^{\circ} \mathrm{C}$, w czasie 4 i 12 godzin i ciśnieniu

Dr inż. Dominik Kukla - Instytut Podstawowych Problemów Techniki PAN, dr inż. Andrzej Zagróski - Politechnika Warszawska. 
150 hPa. Różne czasy ekspozycji w warunkach plazmy pozwoliły otrzymać warstwy o grubości ok. 20 i $40 \mu \mathrm{m}$.

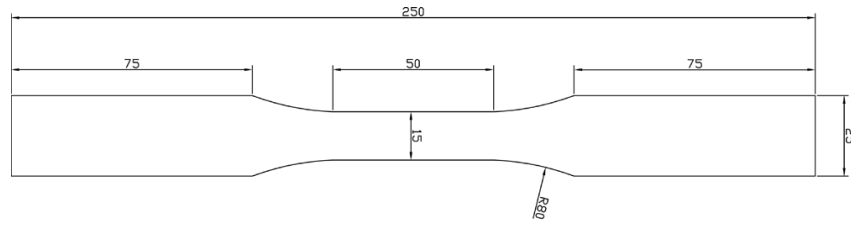

Rys. 1. Geometria próbki do badań zmęczeniowych z wydłużoną częścią pomiarową

Fig. 1. Geometry of specimen for fatigue tests with the elongate of measuring part

Testy zmęczeniowe prowadzono na maszynie wytrzymałościowej MTS $810 \mathrm{w}$ zakresie amplitudy naprężenia naprężenia 500-700 MPa. Badania w zakresie identyfikacji i lokalizacji pękania warstwy aluminidkowej wykonano z zastosowaniem defektoskopu prądowirowego NORTEC 600 oraz kamery ESPI. Próby ustalenia momentu pęknięcia warstwy na stopie niklu z wykorzystaniem kamery ESPI wykonano w czasie prób zmęczeniowych na podstawie rozkładów pól odkształcenia. Do pomiaru przemieszczenia zatrzymywano test zmęczeniowy po ustalonej liczbie cykli i wykonywano pomiar w kilku krokach. Z uwagi na wysoką dokładność metody rejestracji obrazów map fazowych konieczne było zadawanie obciążenia z wykorzystaniem pompy ręcznej, ponieważ hydraulika maszyny zakłócała pomiar. Metodyka pomiaru pokazana na rysunku 2. powtarzana była po ustalonej sekwencji cykli, aż do pęknięcia warstwy poprzedzającego pęknięcie próbki.

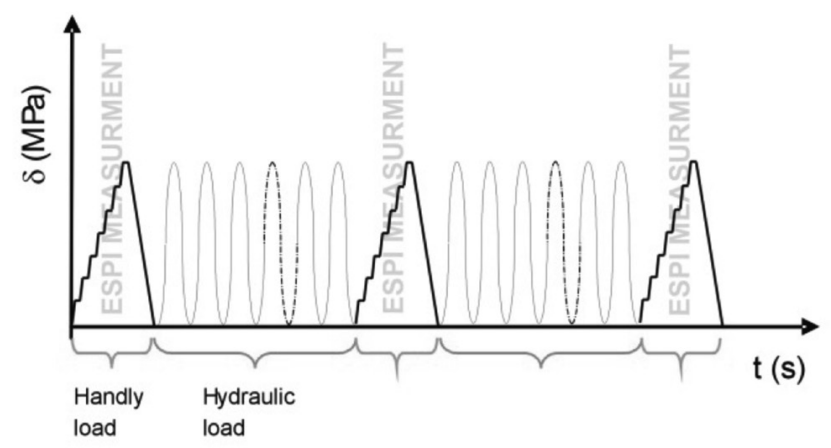

Rys. 2. Schemat obciążenia próbki oraz wykonania pomiarów Fig. 2. Diagram of samples load and take measurements

Dla każdej z badanych próbek z warstwą wykonywano od 5 do 12 obrazów przemieszczenia co pozwoliło obserwować rozwój uszkodzenia próbki w postaci lokalizacji przemieszczenia. Pomiar odkształcenia z zastosowaniem kamery ESPI polega na pomiarze przemieszczenia w oparciu o odkształcenie prążków interferencyjnych widocznych na specjalnie przygotowanej powierzchni próbki, pod wpływem przyłożonego obciążenia. Na rysunku 3 widoczny jest schemat wyznaczania mapy odkształcenia w systemie pomiarowym ESPI.

Badania z zastosowaniem metody prądów wirowych miały charakter diagnostyczny i polegały na wykryciu nieciągłości w materiale próbki w postaci powierzchniowego pęknięcia warstwy. Badania te, polegające na skanowaniu części pomiarowej próbki, wykonywano w czasie zatrzymania testy, przy maksymalnej sile obciążenia równej amplitudzie naprężenia zmęczeniowego, tak aby zwiększyć detekcję potencjalnych pęknięć.

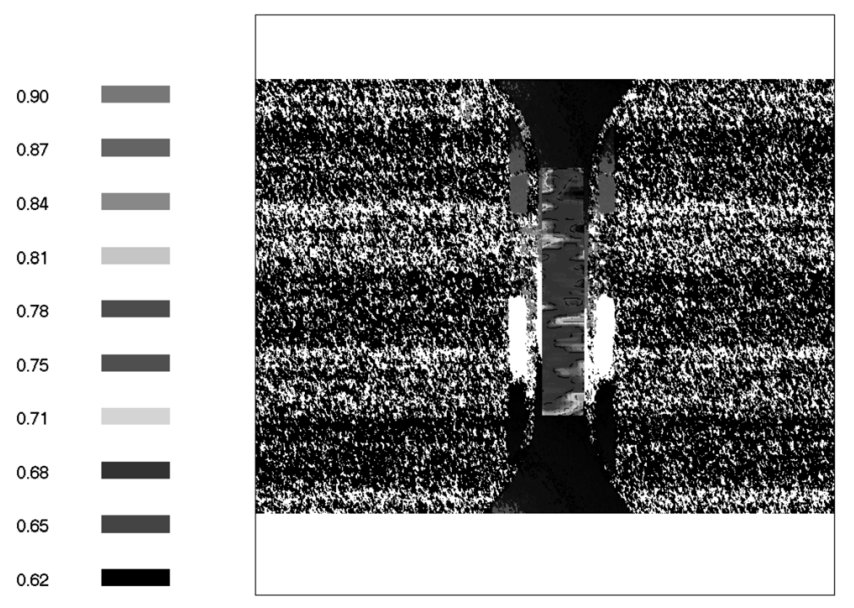

Rys. 3. Obraz interferencyjny z nałożonym obrazem mapy odkształcenia w części pomiarowej próbki wygenerowanym przez system ESPI

Fig. 3. Image of the Interference with superimposed image of the distortion map in the measurement part of the sample generated by the ESPI system

\section{Wyniki}

Wyniki pomiarów pokazano na przykładzie próbki poddanej cyklicznym obciążeniom o amplitudzie $600 \mathrm{MPa}$, w postaci wybranych map odkształcenia (rys. 4.) Pokazano mapy odkształcenia zarejestrowane w pierwszym cyklu zmęczeniowym oraz kolejno po 10, 20, 30, 40 i 50 tysiącach cykli. Próbka pękła po 50155 cyklach, a wartości odkształcenia wyrażono w jednostkach bezwymiarowych $[\mathrm{mm} / \mathrm{mm}]$ * 10-3 (rys. 4).

Na podstawie uzyskanych wyników widać koncentracje odkształcenia w trzech obszarach już po 40000 cykli. Ostatni zarejestrowany obraz wskazuje na silne koncentracje deformacji. Wartości odkształcenia w tych miejscach mogą wskazywać że doszło tam do pęknięć warstwy poprzedzających pęknięcie próbki, do którego doszło w miejscu największej deformacji (górna część próbki). Jednocześnie z pomiarami rozkładu przemieszczenia wykonano pomiary defektoskopowe metodą prądów wirowych, które zidentyfikowały jedno pęknięcie, w obszarze największej deformacji, ale dopiero po 50000 cykli. Na rysunku 5 pokazano krzywe impedancyjne uzyskane na wzorcu o nieciągłościach referencyjnych 0,$1 ; 0,2 ; 0,5$ oraz $1 \mathrm{~mm}$ (rys. 5a) oraz w miejscu pęknięcia, przy naprężeniu zerowym (rys. 5b) oraz naprężeniu $600 \mathrm{MPa}$, równym amplitudzie zmęczeniowej (rys. 5c). Na podstawie analizy porównawczej sygnałów można oszacować wielkość (głębokość) pęknięcia na ok. 0,1-0,2 mm, przy czym widać, że wielkość pęknięcia powiększyła się przy obciążeniu próbki.

Próg detekcji pęknięć dla metody prądów wirowych nie pozwala na identyfikację pęknięć samej warstwy, której grubość dla badanych próbek wynosi 20 lub $40 \mu \mathrm{m}$. Tym niemniej udało się potwierdzić, że w jednym z miejsc koncentracji odkształcenia doszło do nukleacji i rozwoju pęknięcia warstwy, a następnie próbki I w konsekwencji jej dekohezji.

Występowanie licznych pęknięć warstwy poprzedzających pęknięcie próbki wykazały badania fraktograficzne na złomach zmęczeniowych z wykorzystaniem elektronowej mikroskopii skaningowej (SEM). Wyniki widać na przykładowych obrazach powierzchni bocznej próbek (rys. 5). Jednocześnie potwierdzono grubość uzyskanych w procesie CVD warstw aluminidkowych. 


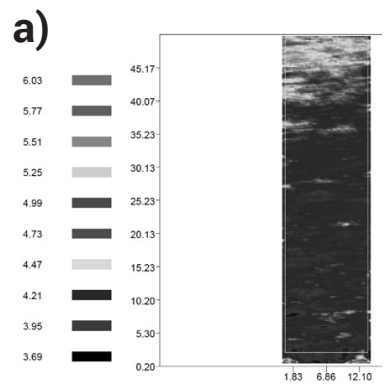

d)

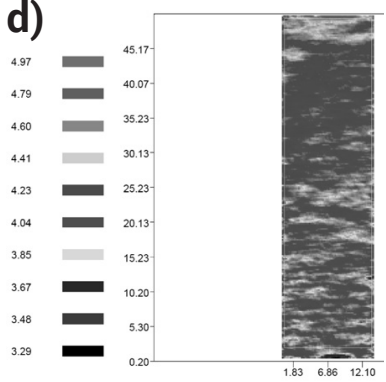

b)

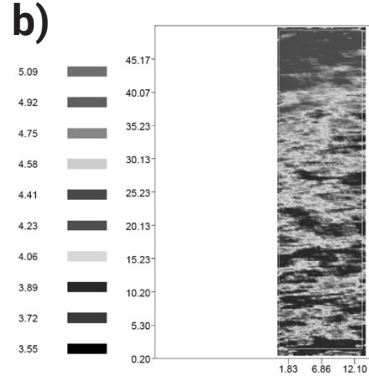

e)

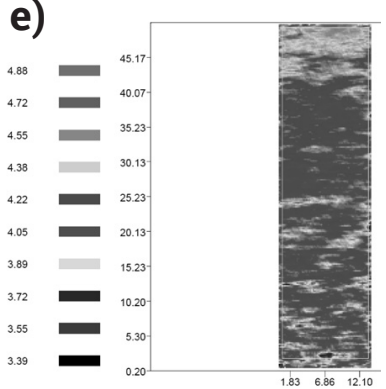

c)

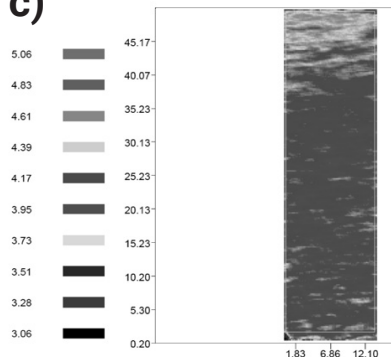

Rys. 4. Mapy odkształcenia na powierzchni próbki poddanej amplitudzie obciążenia $600 \mathrm{MPa}$ uzyskane (a) cyklu nr 1, (b) w cyklu nr 10 001, (c) w cyklu 20 001, (d) w cyklu 30 001, (e) w cyklu 40 001, (f) w cyklu 50001

Fig. 4. Map of deformation on the surface of the sample subjected to the amplitude of the load of $600 \mathrm{MPa}$ obtained (a) of cycle \# 1, (b) a cycle of 10 to 001 , (c) cycle 20001 , (d) cycle 30 001, (e) cycle 40001 (f) in a cycle of 50001
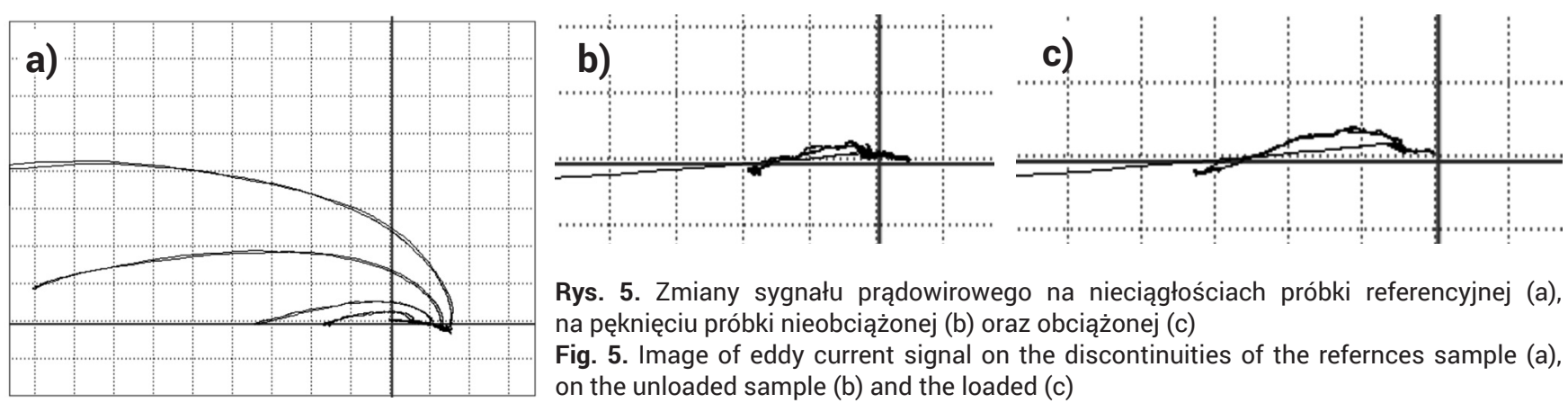

Rys. 5. Zmiany sygnału prądowirowego na nieciągłościach próbki referencyjnej (a), na pęknięciu próbki nieobciążonej (b) oraz obciążonej (c)

Fig. 5. Image of eddy current signal on the discontinuities of the refernces sample (a), on the unloaded sample (b) and the loaded (c)
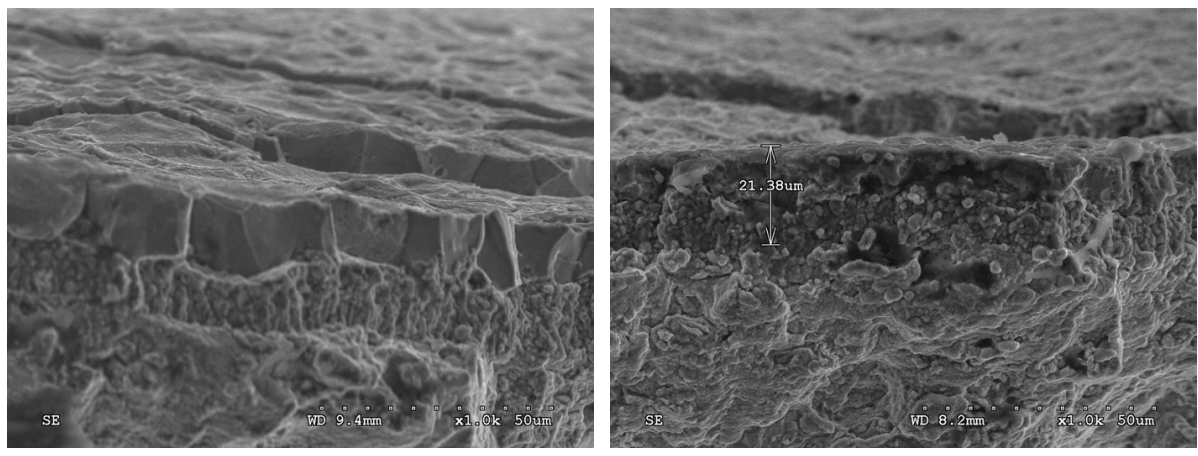

Rys. 6. Obraz pęknięć warstwy aluminidkowej na złomie zmęczeniowym próbki

Fig. 6. Image of the aluminide layer cracks on the scrap fatigue sample

\section{Wnioski}

Identyfikacja i lokalizacja pęknięć warstw aluminidkowych na stopie niklu jest możliwa z zastosowaniem optycznej metody ESPI pozwalającej na generowanie map odkształcenia. Tworzące się podczas cyklicznego obciążenia zmiennego koncentracje odkształcenia mogą wynikać z powstawania pęknięć warstwy inicjujących dalej w głąb materiału. Pęknięcia tego typu, występujące już w końcowej fazie zmęczenia można znaleźć przy pomocy defektoskopowej metody prądów wirowych.

\section{Acknowledgments}

The authors gratefully acknowledge the funding by The National Centre for Research and Development, Poland, under Program for Applied Research, grant no 178781.

\section{Literatura}

[1] Sakaguchi M., Okazaki M.: Fatigue life evaluation of a single crystal Ni-base superalloy, accompanying with change of microstructural morphologyInternational. Journal of Fatigue, 29 (2007), 1959-1965.

[2] Sitek R., Matysiak H., Wisniewski P., Lisowski W, Kurzydlowski K. J.: Effect of glow discharge conditions on the structure and properties of TBC/BC thermal barrier formed on Inconel $713 \mathrm{C}$ nickel superalloy. Frontier of Applied Plasma Technology. 5 (2012), 89-93.

[3] Sitek R., Kukla D., Kobayashi A., Kurzydlowski K. J.: Influence of High-Temperature Aluminizing on the Fatigue and Corrosion Resistance of Nickel Alloy Inconel 740, Frontier of Applied Plasma Technology. Vol. 7, No. 1 January 2014 